\title{
Article
}

\section{Implementing technical refinement in high-level athletics: Exploring the knowledge schemas of coaches}

Kearney, P.E., Carson, H.J., and Collins, D.

Available at http://clok.uclan.ac.uk/18878/

Kearney, P.E., Carson, H.J., ORCID: 0000-0002-3785-606X and Collins, D. ORCID: 0000-0002-7601-0454 (2018) Implementing technical refinement in high-level athletics: Exploring the knowledge schemas of coaches. Journal of Sports Sciences, 36 (10). pp. 1118-1126. ISSN 0264-0414

It is advisable to refer to the publisher's version if you intend to cite from the work. http://dx.doi.org/10.1080/02640414.2017.1358339.

For more information about UCLan's research in this area go to http://www.uclan.ac.uk/researchgroups/ and search for < name of research Group>.

For information about Research generally at UCLan please go to http://www.uclan.ac.uk/research/

All outputs in CLoK are protected by Intellectual Property Rights law, including Copyright law. Copyright, IPR and Moral Rights for the works on this site are retained by the individual authors and/or other copyright owners. Terms and conditions for use of this material are defined in the policies page.

\section{CLoK}

Central Lancashire online Knowledge www.clok.uclan.ac.uk

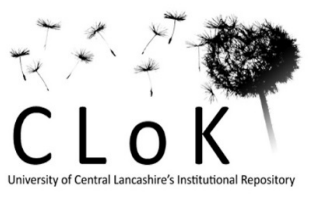


Implementing Technical Refinement in High-Level Athletics: Exploring the Knowledge Schemas of Coaches

PHILIP E. KEARNEY ${ }^{1 *}$, HOWIE J. CARSON ${ }^{2}$, and DAVE COLLINS ${ }^{2}$

${ }^{1}$ Department of Sport \& Exercise Sciences, University of Chichester, Chichester, United

Kingdom

${ }^{2}$ Institute of Coaching and Performance, University of Central Lancashire, Preston, United Kingdom

*Correspondence concerning this paper should be addressed to Philip E. Kearney, Department of Sport \& Exercise Sciences, University of Chichester, Chichester, PO19 6PE, United Kingdom. E-mail: p.kearney@chi.ac.uk. 


\begin{abstract}
This paper explores the approaches adopted by high-level field athletics coaches when attempting to refine an athlete's already well-established technique (long and triple jump and javelin throwing). Six coaches, who had all coached multiple athletes to multiple major championships, took part in semi-structured interviews focused upon a recent example of technique refinement. Data were analysed using a thematic content analysis. The coaching tools reported were generally consistent with those advised by the existing literature, focusing on attaining 'buy-in', utilising part-practice, restoring movement automaticity and securing performance under pressure. Five of the six coaches reported using a systematic sequence of stages to implement the refinement, although the number and content of these stages varied between them. Notably, however, there were no formal sources of knowledge (e.g., coach education or training) provided to inform coaches' decision making. Instead, coaches' decisions were largely based on experience both within and outside the sporting domain. Data offer a useful stimulus for reflection amongst sport practitioners confronted by the problem of technique refinement. Certainly the limited awareness of existing guidelines on technique refinement expressed by the coaches emphasises a need for further collaborative work by researchers and coach educators to disseminate best practice.
\end{abstract}

Keywords: coaching practice, the Five-A Model, horizontal jumps, javelin throwing 
Implementing Technical Refinement in High-Level Athletics: Exploring the Knowledge

\section{Schemas of Coaches}

Sport coaching is a complex, multifaceted but rapidly developing domain, with research offering an ever-increasing understanding of systems, mechanistic underpinnings and coaching 'tools' used to enhance or develop athletes' performance (e.g., Abraham, Collins \& Martindale, 2006; Côté \& Gilbert, 2009). At the same time, expert coaching is understood to be supported by integrated components of such knowledge (e.g., motor control, pedagogy, psychology, etc.) that form a number of schemas (i.e., a mental structure/framework of ideas that underpins behaviour and the perception of new information), each intended to address a particular coaching challenge (Abraham et al., 2006; Collins \& Collins, 2016). In the case of competitive high-level athletes (e.g., horizontal jumpers), attempts to refine already learnt, long practised and wellestablished techniques (Carson \& Collins, 2016a; Minichiello, Rose \& Brice, 2009), should target long-term permanency of the new version and, resistance against the negative effects of competitive pressure (Carson \& Collins, 2011). Unfortunately, while much research has focused on understanding beginner athletes learning skills (e.g., Lidor, 2004) or experienced athletes optimally performing their already acquired skills (e.g., Bell \& Hardy, 2009), considerably less research has addressed and informed coaching practice intended to facilitate technical refinement for high-level athletes.

Reflecting the need for a systematic approach to achieve these aforementioned outcomes, Carson and Collins (2011) proposed the Five-A Model. From a motor control perspective, the already existing and automated movement is de-automated (Awareness stage), adjusted (Adjustment stage) and then re-automated ((Re)Automation stage) as a crucial requirement towards optimal skill execution (Beilock, Carr, MacMahon \& Starkes, 2002; Christina \& Corcos, 
1988). To ensure robustness under competitive pressure however, a final Assurance stage is included to instil confidence and trust in the new execution process. In practical terms, Carson and Collins provide guidance using a combination of mental factors (e.g., imagery of a best attempt self-model and use of holistic auditory rhythm) and practice design (e.g., contrast drills and combination training - combining physical exercises with technically demanding challenges). However, the Five-A-Model also addresses necessary psychosocial factors associated with behavioural intervention in applied settings. Notably, the need for coaches to conduct an initial Analysis stage that promotes athlete 'buy-in', commitment and motivation to carry out change. Accordingly, detailed advice now exists within the literature on the processes and tools which may be expected to best promote technical refinement (see Carson \& Collins, 2011, 2014, 2016b, for an extensive account of each stage).

\section{The Research-Practice Gap: What Evidence Suggests}

For applied coaching research to prove wholly worthwhile, a crucial aspect to consider is its impact within representative settings. Unfortunately, recent attempts to evaluate coaching practice have suggested a consistent discrepancy between current recommendations from the skill acquisition and performance literature and knowledge-bases and/or behaviours of coaches (Cushion, Ford \& Williams, 2012; Low, Williams, McRobert \& Ford, 2013; Millar, Oldham \& Donovan, 2011; Porter, Wu \& Partridge, 2010). A notable limitation of these studies, however, has been coaches' assumed intended training outcomes. Since different skill development objectives, for instance, rapid acquisition, long-term retention and transfer (Kantak \& Winstein, 2012; Schmidt \& Bjork, 1992), or refinement to well-established techniques (Carson \& Collins, 2011) require different practices, it would seem reasonable to consider data collected against the stated aims of the coach. For example, rapid performance gains can be facilitated by practicing 
skill variations in blocks, long-term retention and transfer promoted when these variations are ordered randomly (see also Williams \& Hodges, 2005) and refinement of an already wellestablished skill when this version is contrasted with that of a desired new version (Collins, Morriss \& Trower, 1999). Addressing this limitation, and relevant to this paper's focus on technical refinement, Carson, Collins and MacNamara (2013) examined current refinement knowledge amongst high-level golf coaches. Results showed a clear lack of consistency both within and between coaches and golfers in the approach taken, and low levels of mechanistic/theoretical understanding across the sporting 'ologies' (cf. Abraham et al., 2006), particularly when addressing the requirement to establish resistance of the refined skills against competitive pressure. Accordingly, Carson et al. were able to establish a specific requirement amongst golf coaches, at least, to be further informed about the implementation of technical refinement.

While Carson et al. (2013) found individual coaches reporting systematic approaches to implement technical refinement, albeit with inconsistency in application both between and within coaches, an exploration of the links between each system's mechanistic underpinnings and coaching practices used was not considered as part of the study's aims. Understanding both declarative ('what needs to be done and why') and procedural ('how to do it') components of a coach's knowledge schema may help to inform approaches aimed at disseminating skill refinement research within the context of applied sport science support or coach education (Grecic \& Collins, 2013).

For discrete skills requiring maximal physical effort and explosive power, there is clearly a high need for the technique to remain robust when executing under these conditions (cf. Schmidt, Zelaznik, Hawkins, Frank \& Quinn Jr., 1979). Whereas in golf it is possible, and 
sometimes desirable, to sacrifice $100 \%$ power for increased accuracy, this is clearly not the case for field athletics events where only a single trial counts towards the final result (e.g., horizontal jumping and javelin throwing). In this regard, a cursory review of track and field coaching magazines and training manuals reveals a strong focus on technical models of expert performance, leading to the identification of common flaws in high-level athletes' technique and the modifications necessary to enhance performance (Carr, 1999; Isolehto, Virmavirta, Kryöläinen \& Komi, 2007; Mendoza \& Nixdorf, 2011; Petrov, 2004). In contrast, however, less attention is paid to the athlete's level of automaticity when executing their technique; a factor which has also been shown as crucial for performance success in competitive situations (Bortoli, Bertollo, Hanin \& Robazza, 2012; MacPherson, Collins \& Morriss, 2008). Thus, field athletics appears to be an appropriate domain for this present investigation into coaches' understanding, with its demand for both technical accuracy and maximal effort executions. In particular, horizontal jumping (long and triple) and javelin throwing were chosen due to their being stereotypical short duration, maximal effort and closed skills.

\section{Obtaining a More Accurate Gauge of the Research-Practice Gap: How should we do it?}

Considering the level of detail and rich picture required, interviews are the logical research tool of choice. However, retrospective event recall may be challenging. Sparkes and Smith (2014) recommend several methods by which an interviewee may be supported in this task of information sharing. One possible route to an enhanced understanding of coaches' experiences is to supplement already existing interview techniques (e.g., probes) with the construction of a graphical timeline. Indeed, application of this procedure is already apparent within the applied sport psychology and coaching literature (e.g., in contexts of culture change in elite sport teams and depicting talent development pathways in sport and music; Cruickshank, 
Collins \& Minten, 2013; MacNamara, Collins \& Button, 2010). The benefits of using these timelines can be seen as an aid for recall, structuring or 'phrasing' data and as a means of reviewing the discussed information. As such, applying graphical timelines to elicit discussion of any process — especially longitudinal ones — would make sense, including during investigations into the implementation of technical refinement.

Accordingly, the aim of this study was threefold. Firstly, we wished to investigate the tools used by field athletics coaches, to determine whether their applied practice incorporated elements that had not been considered in the guidance provided by Carson and Collins (2011, 2014, 2016b). Secondly, we were interested in the generality of the finding by Carson et al. (2013): namely, did coaches operationalise refinement within a systematic approach? Thirdly, we wanted to explore the breadth, depth and sources of coaches' declarative knowledge relating to the implementation of technical refinement.

\section{Method}

\section{Design}

Within elite sport, there is a dearth of research investigating the processes used to bring about technical refinement. As such, the application of qualitative methods to generate rich descriptions of participants' processes was deemed appropriate at this stage (Patton, 2002). More specifically, given that technique refinement is likely to be a highly individual and contextual process, interviews with individual coaches was selected as the most appropriate method.

\section{Participants}

Six high-level male coaches with between 16-35 years coaching experience $\left(M_{\text {experience }}=\right.$ 27.8 years, $S D=6.6$ ) were purposively sampled based on having coached multiple athletes to multiple major championships (i.e., Olympic, World Championship, European or 
Commonwealth Games). Additionally, coaches were required to be currently active and to have worked on a technical refinement within the past five years. At the time of data collection, five coaches were qualified at UK Athletics Level 4 and one at Level 3 (see http://ucoach.com/qualifications/coach-education-and-pathway/for equivalent current qualification framework). Ethical approval was granted by the university's ethics committee and all participants provided signed informed consent prior to interviewing.

\section{Procedure}

A semi-structured interview guide was developed based on literature-derived themes to help support the interviewer. Each coach described their current coaching activity, before describing a specific case study of technical refinement by considering the athlete's background, the intended refinement and its rationale. In collaboration with each participant, a graphic timeline was developed which outlined the macro-level progression of the athlete across the coaching process. The $x$-axis was 'time' and the $y$-axis was based on 'percentage progress towards the completed change'. This depiction was then used as a basis to aid recall and frame subsequent probing. In particular, the timeline was used to structure discussion of the specific processes employed and the underpinning rationale (e.g., "so what was happening here?" "Why was that approach used?"). The final section focused on the origin (e.g., "where did an understanding of this process come from?") and generality ("is this the same process that you use with all your athletes?") of the process that had been outlined. Probes were used to elicit greater depth of information as required and to clarify any technical terminology. The interviews, ranging in duration from 55-155 minutes $\left(M_{\text {duration }}=93\right.$ minutes, $\left.S D=35\right)$, were digitally recorded using a Dictaphone.

\section{Data Analysis}


Following guidelines presented by Côté, Salmela, Baria and Russell (1993), interview transcripts were read several times to understand each coach's perspective and meaningful units of text were inductively identified as raw data codes. These meaning units were then clustered together to allow a thematic structure to emerge. Emergent clusters (lower-order, higher-order and general dimensions) were tested until the researcher was satisfied that a workable structure had emerged. Although the data analysis primarily utilised inductive procedures, the final step of the process was a deductive analysis (cf. Fletcher \& Arnold, 2011). More specifically, the guidance provided by Carson and Collins (2011, 2014, 2016b) influenced the designation of the themes and dimensions relating to aims one and two. To enhance the trustworthiness of the data, participants were invited to read their interview to confirm accurate transcription and to elaborate, if necessary, on their responses following a period of self-reflection (Sparkes, 1998). Where it was felt that a portion of the transcript was ambiguous, the participants were asked to clarify or expand upon their point. Five participants offered additional information or clarified elements of the transcript in response to this approach. In addition, agreement between two researchers (the first and second authors) was established at all stages of the coding process. After the lead investigator had completed selection of raw themes, and each level of classification, a discussion was held. Disagreements were discussed until consensus was reached (Sparkes, 1998).

\section{Results}

Results are presented as reflecting the study's three aims. Initially, we explore coaches' procedural knowledge of tools to enact the refinement stages reported. Secondly, we identify coaches' declarative understanding through the extent to which a systematic approach was 
evident and its underpinnings. Finally, the nature and sources of coaches' knowledge of technique refinement is considered.

\section{Coaching Tools to Enact Refinements}

The applied tools that coaches described using to enact technical refinements are presented in Table 1. These applied tools were consistent with those which have previously been reported in accounts of the Five-A Model (see Carson \& Collins, 2011; 2014; 2016b). As such, we will only briefly report on how coaches differed.

The sophistication of reported tool use varied both between stages and between coaches. In contrast to other aspects of the process, for which a range of tools were described, limited information was provided on how automaticity could be actively encouraged. Coaches primarily described high quality repetition as the key, although three coaches transitioned their athlete's attention to a more holistic focus: for instance, "We wanted to build to a crescendo" (Coach 3).

Discussion of automaticity-inducing tools also provided an example of the variation in sophistication between coaches; while Coach 4 only discussed encouraging high quality repetition, Coach 2 described a range of approaches utilised in response to varying athlete characteristics:

“it's repetition of the skill performed accurately. And it's not practice makes perfect, it's perfect practice makes perfect." (Coach 4)

With this particular athlete, [athlete name] tends to want to be instinctive anyway, and my thing was to get him to think a little bit. So at the end of the stage I just stopped asking him too many questions... For another athlete, now, who just loves to think, and I have one of those. Over thinks everything...For them now, we sort of say: 'When you get on the runway, you literally have this amount of time to come down and execute'. (Coach 2) 


\section{Systematic Approaches to Technique refinement}

Five coaches outlined similarly sequential stages (3-4 stages) that they worked through with their athlete (Table 2). The exception, Coach 3, discussed similar objectives (i.e., establish a strong relationship with the athlete, develop the athlete's awareness), but did not explicitly identify stages. An overview of the approaches adopted by the coaches is provided in Table 3 and two exemplars of the timelines constructed by coaches are shown in Figure 1.

All coaches reported a need for analysis prior to any physical modifications. For some, this process simply provided an explanation and rationale for change to the athlete; for others it consisted of a purposefully shared conversation. The extent of athlete involvement therefore varied from a coach-led to an athlete-led approach, as the following quotations describe:

...coaching is not a democracy; it's a benevolent dictatorship. Effective coaching is not by consensus, but by consent. So the athlete consents to having their life run for them, but I don't coach with their consensus, no. (Coach 4)

I set him the challenge: 'Right, I need to know what you think you ought to do, and then we'll have a conversation'. So he was set the task. He knew what he wanted. And now the challenge was: 'Ok, now how are you going to go about this? How is it you want to work?' (Coach 5)

Coach 6 uniquely described a prolonged assessment period as a distinct stage prior to 'selling' the change to the athlete, specifically testing the athlete's readiness to change:

I'll throw them into these situations to see whether they sink or swim...where you find out whether they're prepared to do the nasty stuff...So you've got them in a situation where you discover if they've got what it takes [to make the change] (Coach 6) 
Regarding motor control, all coaches reported developing the athlete's conscious movement awareness as the action was first isolated, then gradually shaped towards the target movement. Despite differences in terminology, for instance, 'appreciation', 'isolation' and 'breaking it down', there was shared meaning across all, as the following quotations demonstrate: "It starts with their awareness of what the bloody hell is going on" (Coach 4); "To get him thinking about what he was trying to do" (Coach 5).

While three coaches focused on the new movement when engaged in this part-skill practice, two coaches explicitly reported the importance of disrupting the existing movement pattern: “...you just want them to do something other than what they were doing before, because that breaks it up" (Coach 2); "Contrast, deliberateness, wipes, can wipe [the existing pattern]" (Coach 5).

Four coaches explained that the movement would need to be returned back to optimal automatic control: "I've always thought that whatever you do you want to create habits, things that you do without thinking" (Coach 6); "It's not sufficiently unconscious. There has to be some concentration to make it happen. It doesn't mean it's not there, but it's not a reflex" (Coach 4).

There was less consistency across coaches when addressing elements of the change process as it moved closer to completion. Specifically, this lack of consistency related to the extent to which the skill was proactively prepared for competition. For three coaches, the need for competitive preparation was expressly identified as a distinct step in the refinement process: "You have to go into the competitive environment, where the pressure is on, and deliver that skill that you've now learnt, when the pressure of expectation, competition, adrenaline; so that's 
another step in the process." (Coach 4); “There's a difference between doing a full run in training and a full run in competition. So next thing is let's try it under the ultimate pressure." (Coach 6).

Given these challenges, the coaches unanimously expressed a preference for making technical changes during the off-season. In three of the cases, even where the need to change was identified within one competitive cycle, the change was postponed until the next off-season:

You have to have a substantial amount of time away from any competitive experience, because if you try to change things and try to compete and the same time, as soon as that gun goes or the competition starts, you fundamentally revert to what you've always done. It's the natural thing. So, in a way, what's the point in doing it during that time because you're constantly going to be making it again, losing it again, making it again, losing it again. (Coach 6)

Contextual demands played a role in shaping the how the systematic approach described by coaches was implemented. All indicated that the stages they outlined provided a general 'formula' that they routinely followed. They further emphasised that the formula was adapted to match the needs of the individual athlete or the technique change in question: "That's my general philosophy, yeah. That's my philosophy. But it changes [in how it is implemented] from athlete to athlete" (Coach 3). An example of a specific adaptation was provided in the previous section when discussing how changes were enacted. Adaptation to the needs of the individual included when to intervene, if at all: 'It's a trade-off...it's going to take a long time to change any skill. You then have to very much weigh a balance between what could you do with the time that you're not going to have." (Coach 6).

\section{The Nature and Sources of Coaches' Knowledge}


None of the coaches were able to identify any formal sources of guidance on how to implement technical change (Table 4). With the expectation of responsibility being on national governing bodies, Coach 5 reported: "It's in absolutely nothing. It's not in the manuals".

Instead, the coaches reported that their practice was an amalgamation of information from many sources, as Coach 3 summarised: "You become a filter. You think: 'I like that' or: 'That goes with that'. I don't know if I've had any original thoughts, but I'm good at putting other people's thoughts together". These sources included previous coaching and personal athletic experience and learning from contacts within athletics including: other coaches, mentors, athletes and sport psychologists. Additionally, two coaches specifically mentioned transferring sources of knowledge from their wider reading, including self-help books and experiences gained from working in a school setting.

Three coaches emphasised the need for a breadth of refinement approaches in order to meet the varied challenges posed by different athletes. This position was explained by Coach 6 using the following analogy: "I've got this awkward screw. What I have got is this huge toolbox, and one of those bastards is going to fit it; it might just take me some time to find the right tool". Coach 5, however, offered the critique that coaches typically lack sufficient depth of knowledge to allow such flexibility required: “[Coaches] they’ve got a way of doing it, and therefore the way they'll do it, and they won't really find out, be innovative or inquisitive about different ways of doing it."

Despite the need to possess a range of approaches, during this discussion three coaches emphasised the need to be critical of new information: "I'd never go: 'Oh, all my stuff's rubbish', or 'This is the new thing'. I think you've just always got to be careful" (Coach 1). 


\section{Discussion}

The aim of this study was threefold. Firstly, we investigated the tools used by field athletics coaches, to determine whether their applied practice incorporated elements that had not been considered in the guidance provided by Carson and Collins (2011, 2014, 2016b). Secondly, we examined the generality of the finding by Carson et al. (2013) that coaches apply these tools in a common, systematic approach. Thirdly, we explored the breadth, depth and sources of coaches' declarative knowledge relating to the implementation of technical refinement.

Tools reported by coaches were contained within those recommended by the Five-A Model (Carson \& Collins, 2011, 2014, 2016b). Given that the model was derived from applied literature and for coaches, this finding is positive if unsurprising. Additionally, however, there were tools which are prominently featured within the Five-A Model and related case studies of technique refinement (Carson et al., 2014; Collins et al., 1999) which did not feature within individual coaches' accounts. For example, given that the teaching of imagery is a central pillar of applied sport psychologists' work (Cumming \& Williams, 2011), it is surprising that three of the coaches made no mention of imagery. There is considerable evidence of the effectiveness of imagery within skilled populations (e.g., Bortoli et al., 2012), who frequently report its use under high-anxiety conditions (Murphy, Nordin \& Cumming, 2008). Thus, coaches should be encouraged to review the range of tools applied to the problem of technique refinement (potentially utilising Table 1 as a stimulus), to consider whether additional tools may be applied to enhance the effectiveness of their approaches.

The majority of coaches were found to apply a systematic approach to technique refinement. As with tool use, inter-individual variations in the content and sophistication of the approaches were evident, such that no one coach fully implemented the entire Five-A Model 
process. In particular, and reflecting the current status as depicted within popular athletics texts (Carr, 1999; Isolehto et al., 2007; Mendoza \& Nixdorf, 2011; Petrov, 2004), several coaches made no or limited comment on the need to re-automate the refined technique, or to the need to ensure that the refined technique would be maintained under the rigour of competition. The absence of commentary on these stages in some individuals suggests that high-level field athletics coaches may benefit from considering the macro-process of technique refinement in greater depth (cf. Carson et al., 2013).

Although guidelines for addressing technique refinement exist within the academic (Carson \& Collins, 2011; Hanin \& Hanina, 2009) and industry literature (Tomlins, 2016), along with a small number of case studies (e.g., Carson et al., 2014; Carson \& Collins, 2015; Collins et al., 1999; Hanin et al., 2002), the current sample did not identify any formal guidelines for its implementation. There is growing evidence that the process for refining technique is subtly, but importantly, different from that of acquiring technique. As such, considering that coaches showed varying degrees of sophistication in their accounts of the stages of technique refinement, and the tools used to enact these stages, it is imperative that increased efforts are made to promote existing models and their application into applied practice. Consistent with previous research (Erikson, Bruner, MacDonald \& Côté, 2008; Stoszkowski \& Collins, 2016), the coaches' primary sources of knowledge regarding technique refinement were based upon their own coaching experiences and their interactions with other coaches. Consequently, descriptive accounts of high-level coaching practice, based on cases such as those provided by the coaches in this study, may be of value as stimuli for reflection within coach development (Douglas \& Carless, 2008). 
The primary limitation of this study was the use of retrospective recall. Although a graphical technique was used to support coaches in their recollection of information (Cruickshank et al., 2013; MacNamara et al., 2010), future designs would benefit from integrating both observation and interview (Collins \& Collins, 2015; Partington \& Cushion, 2013) or considering the use of diary methods (Day \& Thatcher, 2009; Sparkes \& Smith, 2014). Such observations, particularly if undertaken longitudinally, would also present an opportunity to further study how coaches adapt to specific circumstances; that is, such studies would allow researchers and coaches to better understand the coherence between macro-, meso- and microlevels of intervention planning. A related limitation is that the generation of coaching knowledge may be tacit (Nash \& Collins, 2006) and hence coaches may not be in a position to accurately report all of the origins of their knowledge. Nonetheless, it is suggested that expert coaches require an extensive foundation of declarative knowledge before they can effectively utilise 'skilled intuition' (Abraham et al., 2006; Collins, Collins \& Carson, 2016; Nash \& Collins, 2006), and therefore it is particularly concerning that none of the coaches reported any explicit knowledge of specific approaches to technique refinement.

In conclusion, six high-level field athletics coaches provided an overview of the approaches they used to refine an athlete's well-learnt technique. The tools and approaches described within this paper offer useful stimuli for reflection for coaches, sport psychologists and sport scientists confronted by the problem of technique refinement. Critically, the coaches showed varying degrees of sophistication in their accounts of the stages of technique refinement, and the tools used to enact these stages. This finding, taken together with the limited awareness of existing guidelines expressed by the coaches, emphasises the need for further collaborative work by researchers and coach educators to disseminate best practice with regard to technique 
refinement. With regard to coaches' knowledge schemas, findings support the widespread need for stronger association and integration across sporting disciplines such as motor control (practice design) and sport psychology (focus of attention/imagery; Collins \& Carson, 2017) which should form a targeted focus of future research inquiry. 


\section{References}

Abraham, A., Collins, D., \& Martindale, R. (2006). The coaching schematic: Validation through expert coach consensus. Journal of Sports Sciences, 24, 549-564. doi:10.1080/02640410500189173

Beilock, S. L., Carr, T. H., MacMahon, C., \& Starkes, J. L. (2002). When paying attention becomes counterproductive: Impact of divided versus skill-focused attention on novice and experienced performance of sensorimotor skills. Journal of Experimental Psychology: Applied, 8, 6-16. doi:10.1037//0176-898X.8.1.6

Bell, J. J., \& Hardy, J. (2009). Effects of attentional focus on skilled performance in golf. Journal of Applied Sport Psychology, 21, 163-177. doi:10.1080/10413200902795323

Bortoli, L., Bertollo, M., Hanin, Y., \& Robazza, C. (2012). Striving for excellence: A multiaction plan intervention model for Shooters. Psychology of Sport and Exercise, 13, 693701. doi:10.1016/j.psychsport.2012.04.006

Carr, G. (1999). Fundamentals of track and field (2 ${ }^{\text {nd }}$ ed.). Champaign, IL: Human Kinetics.

Carson, H. J., \& Collins, D. (2011). Refining and regaining skills in fixation/diversification stage performers: The Five-A Model. International Review of Sport and Exercise Psychology, 4, 146-167. doi:10.1080/1750984x.2011.613682

Carson, H. J., \& Collins, D. (2014). Effective skill refinement: Focusing on process to ensure outcome. Central European Journal of Sport Sciences and Medicine, 7, 5-21.

Carson, H.J., \& Collins, D. (2015).Tracking technical refinement in elite performers: The good, the better, and the ugly. International Journal of Golf Science, 4, 67-87. doi:10.1123/ijgs.2015-0003 
Carson, H. J., \& Collins, D. (2016a). The fourth dimension: A motoric perspective on the anxiety-performance relationship. International Review of Sport and Exercise Psychology, 9, 1-21. doi:10.1080/1750984X.2015.1072231

Carson, H. J., \& Collins, D. (2016b). Implementing the Five-A Model of technical refinement: Key roles of the sport psychologist. Journal of Applied Sport Psychology, 28, 392-409. doi:10.1080/10413200.2016.1162224

Carson, H. J., Collins, D., \& Jones, B. (2014). A case study of technical change and rehabilitation: Intervention design and interdisciplinary team interaction. International Journal of Sport Psychology, 45, 57-78. doi:10.7352/IJSP.2014.45.057

Carson, H. J., Collins, D., \& MacNamara, Á. (2013). Systems for technical refinement in experienced performers: The case from expert-level golf. International Journal of Golf Science, 2, 65-85. doi:10.1123/ijgs.2.1.65

Christina, R. W., \& Corcos, D. M. (1988). Coaches guide to teaching sport skills. Champaign, IL: Human Kinetics.

Collins, D., \& Carson, H.J. (2017). The future for PETTLEP: A modern perspective on an effective and established tool. Current Opinion in Psychology, 16, 12-16. doi:10.1016/j.copsyc.2017.03.007

Collins, D., Collins, L., \& Carson, H.J. (2016). "If it feels right, do it”: Intuitive decision making in a sample of high-level sport coaches. Frontiers in Psychology, 7, 504. doi:10.3389/fpsyg.2016.00504

Collins, D., Morriss, C., \& Trower, J. (1999). Getting it back: A case study of skill recovery in an elite athlete. Sport Psychologist, 13, 288-298. doi:10.1123/tsp.13.3.288 
Collins, L., \& Collins, D. (2015). Integration of professional judgement and decision-making in high-level adventure sports coaching practice. Journal of Sports Sciences, 33, 622-633. doi:10.1080/02640414.2014.953980

Collins, L., \& Collins, D. (2016). Professional judgement and decision-making in the planning process of high-level adventure sports coaching practice. Journal of Adventure Education and Outdoor Learning, 16, 256-268. doi:10.1080/14729679.2016.1162182

Côté, J., \& Gilbert, W. (2009). An integrative definition of coaching effectiveness and expertise. International Journal of Sports Science \& Coaching, 4, 307-323. doi:10.1260/174795409789623892

Côté, J., Salmela, J. H., Baria, A., \& Russell, S. J. (1993). Organizing and interpreting unstructured qualitative data. The Sport Psychologist, 7, 127-137. doi:10.1123/tsp.7.2.127

Cruickshank, A., Collins, D., \& Minten, S. (2013). Culture change in a professional sports team: Shaping environmental contexts and regulating power. International Journal of Sports Science and Coaching, 8, 271-290. doi:10.1260/1747-9541.8.2.271

Cumming, J., \& Williams, S.E. (2012). Imagery: The role of imagery in performance. In S. Murphy (Ed.), Oxford handbook of sport and performance psychology. New York, NY: Oxford University Press.

Cushion, C., Ford, P. R., \& Williams, A. M. (2012). Coach behaviours and practice structures in youth soccer: Implications for talent development. Journal of Sports Sciences, 30, 16311641. doi:10.1080/02640414.2012.721930 
Day, M., \& Thatcher, J. (2009). "I'm really embarrassed that you're going to read this...”:

Reflections on using diaries in qualitative research. Qualitative Research in Psychology, 6, 249-259. doi:10.1080/14780880802070583

Douglas, K., \& Carless, D. (2008). Using Stories in coach education. International Journal of Sports Science \& Coaching, 3, 33-49. doi:10.1260/174795408784089342

Erickson, K., Bruner, M. W., MacDonald, D. J., \& Côté, J. (2008). Gaining Insight into Actual and Preferred Sources of Coaching Knowledge International Journal of Sports Science \& Coaching, 3, 527-538. doi:10.1260/174795408787186468

Fletcher, D., \& Arnold, R. (2011). A qualitative study of performance leadership and management in elite sport. Journal of Applied Sport Psychology, 23, 223-242. doi:10.1080/10413200.2011.559184

Grecic, D., \& Collins, D. (2013). The epistemological chain: Practical applications in sports. Quest, 65, 151-168. doi:10.1080/00336297.2013.773525

Hanin, Y. L., \& Hanina, M. (2009). Optimization of performance in top-level athletes: An action-focused coping approach. International Journal of Sports Science and Coaching, 4, 47-91. doi:10.1260/1747-9541.4.1.47

Hanin, Y. L., Korjus, T., Jouste, P., \& Baxter, P. (2002). Rapid technique correction using Old Way/New Way: Two case studies with Olympic athletes. The Sport Psychologist, 16, 7999. doi:10.1123/tsp.16.1.79

Isolehto, J., Virmavirta, M., Kryöläinen, H., \& Komi, P. (2007). Biomechanical analysis of the high jump at the 2005 IAAF World Championships in Athletics. New Studies in Athletics, 22(2), 17-27. Retrieved from http://www.iaaf.org/development/new-studies-in-athletics 
Kantak, S. S., \& Winstein, C. J. (2012). Learning-performance distinction and memory processes for motor skills: a focused review and perspective. Behavioural Brain Research, 228, 219-231. doi:10.1016/j.bbr.2011.11.028

Lidor, R. (2004). Developing metacognitive behaviour in physical education classes: the use of task-pertinent learning strategies. Physical Education and Sport Pedagogy, 9, 55-71. doi:10.1080/1740898042000124

Low, J., Williams, A. M., McRobert, A. P., \& Ford, P. R. (2013). The microstructure of practice activities engaged in by elite and recreational youth cricket players. Journal of Sports Sciences, 31, 1242-1250. doi:10.1080/02640414.2013.778419

MacNamara, Á., Collins, D., \& Button, A. (2010). The role of psychological characteristics in facilitating the pathway to elite performance part 2: Examining environmental and stagerelated differences in skills and behaviors. The Sport Psychologist, 24, 74-96. doi:10.1123/tsp.24.1.74

MacPherson, A., Collins, D., \& Morriss, C. (2008). Is what you think what you get? Optimizing mental focus for technical performance. The Sport Psychologist, 22, 288-303. Doi: 10.1123/tsp.22.3.288

Mendoza, L., \& Nixdorf, E. (2011). Biomechanical analysis of the horizontal jumping events at the 2009 IAAF World Championships in Athletics. New Studies in Athletics, 26(3/4), 2560. Retrieved from http://www.iaaf.org/development/new-studies-in-athletics

Millar, S.-K., Oldham, A., \& Donovan, M. (2011). Coaches's self-awareness of timing, nature and intent of verbal instructions to athletes. International Journal of Sports Science and Coaching, 6, 503-514. doi:10.1260/1747-9541.6.4.503 
Minichiello, T., Rose, A., \& Brice, P. (2009, November). Comeback...The team Jennis way. Paper presented at the UK Sport World Class Performance Conference, Sutton Coldfield, UK.

Murphy, S., Nordin, S. M., \& Cumming, J. (2008). Imagery in sport, exercise and dance. In T. Horn (Ed.), Advances in sport and exercise psychology ( $3^{\text {rd }}$ ed., pp. 297-324). Champaign, IL: Human Kinetics.

Nash, C., \& Collins, D. (2006). Tacit knowledge in expert coaching: Science or art? Quest, 58, 465-477. doi:10.1080/00336297.2006.10491894

Partington, M., \& Cushion, C. (2013). An investigation of the practice activities and coaching behaviors of professional top-level youth soccer coaches. Scandinavian Journal of Medicine \& Science in Sports, 23, 374-382. doi:10.1111/j.1600-0838.2011.01383.x

Petrov, V. (2004). Pole vault - the state of the art. New Studies in Athletics, 19(3), 23-32. Retrieved from http://www.iaaf.org/development/new-studies-in-athletics

Porter, J. M., Wu, W. F. W., \& Partridge, J. A. (2010). Focus of attention and verbal instructions: Strategies of elite track and field coaches and athletes. Sport Science Review, 19, 199211. doi:10.2478/v10237-011-0018-7

Schmidt, R. A., \& Bjork, R. A. (1992). New conceptualizations of practice - common principles in three paradigms suggest new concepts for training. Psychological Science, 3, 207-217. doi:10.1111/j.1467-9280.1992.tb00029.x

Schmidt, R. A., Zelaznik, H., Hawkins, B., Frank, J. S., \& Quinn, J. T., Jr. (1979). Motor-output variability: A theory for the accuracy of rapid motor acts. Psychological Review, 47, 415451. 
Sparkes, A. C. (1998). Validity in qualitative inquiry and the problem of criteria: Implications for sport psychology. The Sport Psychologist, 12, 363-386. doi: 10.1123/tsp.12.4.363

Sparkes, A. C., \& Smith, B. (2014). Qualitative research methods in sport, exercise and health: From process to product. London: Routledge.

Stoszkowski, J., \& Collins, D. (2016). Sources, topics and use of knowledge by coaches. Journal of Sport Sciences, 34, 794-802. doi:10.1080/02640414.2015.1072279

Tomlins, K. (2016). Making technical changes. Coaching Insight, 6, 48-53.

Williams, A.M., \& Hodges, N.J. (2005). Practice, instruction and skill acquisition in soccer: Challenging tradition. Journal of Sports Sciences, 23, 637-650. doi:10.1080/02640410400021328 
Table 1.

Tools that coaches reported when attempting technique refinement.

\begin{tabular}{|c|c|c|c|}
\hline $\mathbf{N}$ & Raw data codes & Lower-order Themes & Higher-order Themes \\
\hline 6 & In-depth explanation & \multirow{3}{*}{ Buy in } & \multirow{3}{*}{ Buy in } \\
\hline 3 & Peer modelling & & \\
\hline 1 & Dropping hints & & \\
\hline 6 & $\begin{array}{l}\text { Adopt a narrow internal } \\
\text { focus of attention }\end{array}$ & \multirow{6}{*}{ Awareness } & \multirow{9}{*}{ Part practice } \\
\hline 5 & Questioning the athlete & & \\
\hline 5 & Video replay & & \\
\hline 3 & Contrast drills & & \\
\hline 1 & Novel movements & & \\
\hline 1 & $\begin{array}{l}\text { Providing reduced summary } \\
\text { feedback }\end{array}$ & & \\
\hline 3 & Imagery & \multirow{3}{*}{ Shaping } & \\
\hline 2 & Contextual interference & & \\
\hline 1 & Overlearning & & \\
\hline 4 & Repetition & Repetition & \multirow{4}{*}{ Automaticity } \\
\hline 3 & Holistic focus (e.g., rhythm) & \multirow{3}{*}{$\begin{array}{l}\text { Manipulate } \\
\text { attentional focus }\end{array}$} & \\
\hline 2 & $\begin{array}{l}\text { Remove instruction, more } \\
\text { 'hands off' approach }\end{array}$ & & \\
\hline 1 & Restrict time for execution & & \\
\hline 2 & Training under aerobic & \multirow{3}{*}{$\begin{array}{l}\text { Simulating } \\
\text { pressure in } \\
\text { training }\end{array}$} & \multirow{6}{*}{$\begin{array}{l}\text { Securing performance } \\
\text { under pressure }\end{array}$} \\
\hline & fatigue & & \\
\hline 1 & $\begin{array}{l}\text { Training to complete } \\
\text { technically difficult } \\
\text { challenges }\end{array}$ & & \\
\hline 3 & $\begin{array}{l}\text { Adopt process focus in } \\
\text { competition }\end{array}$ & \multirow{3}{*}{$\begin{array}{l}\text { Managing pressure } \\
\text { in competition }\end{array}$} & \\
\hline 2 & Select level of competition & & \\
\hline 2 & $\begin{array}{l}\text { Manage competition } \\
\text { environment }\end{array}$ & & \\
\hline 2 & Reflection on what and how & Reflection & Generic tools \\
\hline
\end{tabular}

Note. $\mathrm{N}$ indicates the number of coaches who commented on each code. 
Table 2.

Systematic approaches to technique refinement

\begin{tabular}{|c|c|c|c|c|c|}
\hline & Coach 1 & Coach 2 & Coach 4 & Coach 5 & Coach 6 \\
\hline Step 1 & $\begin{array}{l}\text { Questioning/ } \\
\text { Explaining }\end{array}$ & Explanation & $\begin{array}{l}\text { Inform the } \\
\text { athlete }\end{array}$ & $\begin{array}{l}\text { Have a } \\
\text { conversation }\end{array}$ & $\begin{array}{l}\text { Prolonged } \\
\text { assessment }\end{array}$ \\
\hline Step 2 & Understanding & Appreciation & $\begin{array}{l}\text { Break things } \\
\text { down to the } \\
\text { basics }\end{array}$ & $\begin{array}{l}\text { Isolation } \\
\text { phase }\end{array}$ & $\begin{array}{l}\text { Convince } \\
\text { them }\end{array}$ \\
\hline Step 3 & $\begin{array}{l}\text { Building up } \\
\text { towards } \\
\text { competition }\end{array}$ & $\begin{array}{l}\text { Linking/ } \\
\text { Chaining }\end{array}$ & $\begin{array}{l}\text { Build it up to } \\
\text { the full } \\
\text { movement }\end{array}$ & $\begin{array}{l}\text { Adaptation } \\
\text { phase }\end{array}$ & $\begin{array}{l}\text { Break it down } \\
\text { and ease it up }\end{array}$ \\
\hline Step 4 & & Whole Skill & $\begin{array}{l}\text { Prepare to } \\
\text { deliver in } \\
\text { competition }\end{array}$ & & Test it \\
\hline
\end{tabular}


Table 3.

How coaches bring about technique refinement.

\begin{tabular}{|c|c|c|c|c|}
\hline $\mathbf{N}$ & Raw data codes & $\begin{array}{l}\text { Lower-order } \\
\text { Themes }\end{array}$ & $\begin{array}{l}\text { Higher-order } \\
\text { Themes }\end{array}$ & $\begin{array}{l}\text { General } \\
\text { dimensions }\end{array}$ \\
\hline 5 & Stage approach & Format of coaches' & & \\
\hline 6 & $\begin{array}{l}\text { Framework adapted" } \\
\text { to individual/task } \\
\text { Timeframe cannot } \\
\text { be predicted in } \\
\text { advance }\end{array}$ & $\begin{array}{l}\text { Contextual } \\
\text { demands within } \\
\text { coaching }\end{array}$ & & $\begin{array}{l}\text { Representation } \\
\text { of approach } \\
\text { taken }\end{array}$ \\
\hline 3 & Consider if change & & & \\
\hline 1 & $\begin{array}{l}\text { is a priority } \\
\text { Test if the athlete is } \\
\text { ready to change }\end{array}$ & Analysis & & \\
\hline 6 & Establish trust & & & \\
\hline 6 & $\begin{array}{l}\text { Athlete } \\
\text { involvement }\end{array}$ & Buy in & factors & \\
\hline 6 & $\begin{array}{l}\text { Implement changes } \\
\text { away from } \\
\text { competition }\end{array}$ & $\begin{array}{l}\text { Securing } \\
\text { performance under }\end{array}$ & & $\begin{array}{l}\text { Mechanisms to } \\
\text { bring about }\end{array}$ \\
\hline 4 & $\begin{array}{l}\text { Learn to deliver } \\
\text { under pressure }\end{array}$ & pressure & & change \\
\hline 6 & $\begin{array}{l}\text { Conscious } \\
\text { awareness }\end{array}$ & & & \\
\hline 6 & $\begin{array}{l}\text { Technical and } \\
\text { representational } \\
\text { shaping }\end{array}$ & Part Practice & $\begin{array}{l}\text { Motoric } \\
\text { factors }\end{array}$ & \\
\hline 4 & $\begin{array}{l}\text { The best } \\
\text { performances are } \\
\text { automatic }\end{array}$ & Automaticity & & \\
\hline
\end{tabular}

Note. $\mathrm{N}$ indicates the number of coaches who commented on each code. 
Table 4.

Coaches' knowledge of technical refinement.

\begin{tabular}{|c|c|c|c|}
\hline $\mathbf{N}$ & Raw data codes & Lower-order Themes & Higher-order Themes \\
\hline 6 & $\begin{array}{l}\text { Not aware of any } \\
\text { formal guidance }\end{array}$ & $\begin{array}{l}\text { Formal guidance for } \\
\text { implementing } \\
\text { technique refinement }\end{array}$ & \\
\hline 4 & $\begin{array}{l}\text { Experience as an } \\
\text { athlete }\end{array}$ & & \\
\hline 4 & $\begin{array}{l}\text { Previous coaching } \\
\text { experience }\end{array}$ & Own experiences & \\
\hline 2 & $\begin{array}{l}\text { Other sources (e.g., } \\
\text { work in schools) }\end{array}$ & & Sources of knowledge \\
\hline 6 & $\begin{array}{l}\text { Sharing knowledge } \\
\text { with other coaches }\end{array}$ & & \\
\hline 2 & Other athletes & Learning from others & \\
\hline 2 & $\begin{array}{l}\text { Support from sport } \\
\text { psychologists }\end{array}$ & & \\
\hline 3 & $\begin{array}{l}\text { Critically reflect on } \\
\text { new knowledge }\end{array}$ & & \\
\hline 3 & $\begin{array}{l}\text { Broad procedural } \\
\text { knowledge (e.g., } \\
\text { coaching tools }\end{array}$ & Use of knowledge & Use of knowledge \\
\hline & available in context) & & \\
\hline
\end{tabular}

Note. $\mathrm{N}$ indicates the number of coaches who commented on each code. 
